\title{
Failed promises: economic integration, bureaucratic encounters, and the EU-Turkey Customs Union
}

\author{
Bilge Firat
}

(C) Springer Science+Business Media Dordrecht 2012

\begin{abstract}
European integration is based upon the promise to bring prosperity by creating economic and social equilibrium among member states and its regions via integrationist policies jointly managed by states and the institutions of the EU. As one common market initiative for greater economic integration in the wider region, goods circulate without tariff and customs duty barriers in the EU's common customs area. Turkey, not an EU member, has been in this common market since 1996. The EU-Turkey Customs Union, which promised to bring deeper economic and political integration through eventual Turkish membership, represents Turkey's aspirations to move from the periphery of Europe into its core. As an anthropological contribution to investigations of advanced European capitalism, this paper examines fundamental conflicts of interest between the EU and Turkey and locates them in their unequal power relations and in the disjuncture of each side's overall objectives from economic integration. Most importantly, it shows that these interest conflicts have ramifications at the individual bureaucratic level and in daily bureaucratic practice. Dramatic expressions of Turkish state power, which are initially geared toward balancing out power inequities, exacerbate Turkish and EU officials' failures to maintain at least a facade of mutually sustainable interests. Interpreted by EU officials as Turkish bureaucratic inertia, such disintegration of interests has implications for ongoing economic integration and membership negotiations between the two parties, with Turkish officials experiencing loss of control. The paper calls for a critical political economy that pays due attention to the cultural settings in which the former is embedded.
\end{abstract}

Keywords Turkey · The European Union · Customs union · Economic integration · Interests · Bureaucracy

B. Firat $(\bowtie)$

Department of Humanities and Social Sciences, Faculty of Arts and Letters, Istanbul Technical University, Ayazaga Campus, Sariyer, Istanbul 34469, Turkey e-mail: bfirat@itu.edu.tr 


\section{Introduction}

European integration is reputedly based on a promise to bring prosperity and wealth to the wider region by creating economic and social equilibrium among states via integrationist policies. Part of the European Union's (EU) promise in bringing prosperity to member states is to bring political stability and capitalist dynamism into the European peripheries. The promise of peripheral development, however, is at odds with much of the critical literature on economic change, which asserts, for example, that the capitalist world-system and its regions are inevitably divided into core and peripheral regions with unequal wealth, access to capital and technologies, levels of development of labor power, and so forth. At the same time, it leaves open what its consequences will be for different groups in the Euro periphery if regional integration, as promised, brings wealth there. At a more essential level, the promise inherent in European integration does not account for how power over political economic processes and the policies that are embedded within them will be distributed between the core and the periphery, and within the periphery itself, and particularly the role of culture and cultural practices in reproducing power relations.

This paper investigates the case of the EU-Turkey Customs Union within the context of Turkey's ongoing accession to the EU since 2005. The EU-Turkey Customs Union constitutes a significant moment in Turkey's recasting of its ambitions in the capitalist world-system, from a large and relatively powerful semiperipheral country to a core country, as promised by the accession prospect. Yet, once one looks into the deep processes of integration by which this recasting is supposed to occur, one finds that bureaucratic encounters between two unequal sides, both representing competing "constituencies"-one of the European core, one of a peripheral player-contain different interests that are reflected in different cultural practices that may actually impede progress. After reviewing some of the documentary evidence about how the integration process is managed between the EU and Turkey, this study then examines ethnographically how unequal and competing political economic interests are reflected in and reinforced by bureaucratic cultures and practices.

Customs regimes are directly related to a state's economic and political sovereignty, in terms of its ability to freely make economic policies in its territory. Not only are customs a source of revenues but also a way to eliminate outside competition for a state's economic claimants (Tilly 1985:181). With respect to the ongoing regionalization in Europe, EU member states increasingly share political economic sovereignties with EU institutions, most notably with the European Commission (EC). As the EU has become more of an economic zone with its own common internal market (Wolters 2001; Malaby 2002; Rosamond 2002; Reinhardt 2004), economic and other sovereignties are pooled (Sassen 1996; Keohane 2002). A common customs regime is an essential part of the EU's move toward becoming more like a supranational state. As part of a worldwide trend in global convergence and standardization of customs rules (Chalfin 2010:29, 163-191), the EU (through the Commission) became the sole authority in this area, not by directly collecting taxes as classical states do (Sassen 2006) but by instituting and managing a customs regime that is common to all EU member states. The EU-Turkey Customs Union 
represents Turkey's aspirations to join in this pool of European sovereignties and its acceptance of the core EU claim that doing so is in the joint self-interests of core and peripheral states alike.

In order to get to the root of these processes, however, one must account for the contradictions that are inherent in regional/global integration. One common approach is conventional world-systems analysis, which proposes that the capitalist world-system is made up of a single axial division of labor that reproduces global and regional inequality among regions of the core, periphery, and semiperiphery (Turkey, like the recent EU accession countries, being a clear member of the last category). Put simply, that system was produced and is reproduced by processes of incorporation and peripheralization, wherein regions or countries are subject to the imposition of core-oriented political, financial, and material infrastructures; economic units of production and distribution; and labor relations. Under such conditions, upward mobility, as is promised to its peripheries by EU integration, is highly unlikely. To the extent that it occurs, it will mainly help a small group of elites whose interests are tied with those of core European capital. ${ }^{1}$

While this may oversimplify the world-systems approach, many critics from sociology (Arrighi 1994; Burawoy et al. 2000; O'Hearn 2001; Bunker and Ciccantell 2005; Tomich 2003) and anthropology (Kearney 1995; Tsing 2000; Roseberry 2002; Wolf 1992) have proposed that the totality of the world-system can only be understood if it is studied as a relational phenomenon where research and analysis expose the linkages and mutually constituting interactions, that is, the dialectics, between the local and the global. In the words of Roseberry (2002:64):

Institutions, powers, agencies, resources, and resistances will always necessarily be locally figured (again, at both "core" and "periphery" locations), and this is why any attempt to understand such dynamics solely or primarily in terms of the "system" or the relationship of "periphery" to "core" will always fail. Thus, ethnography, understood here as the attempt to understand a local configuration of relationships and understandings, powers, and resistances, is necessary to any understanding of the making of the modern world. Because local relations are also embedded within accumulation processes of wider scope, however, the definition of significant local actors, relations and understandings must make those wider processes and relations internal to their conception of the local. For such understandings, a flexible concept of the social field-one that stresses context, that traces networks, and that defines its central terms and units (including the "local" and the "global") as relations rather than essences-is necessary.

Roseberry emphasizes the importance of employing ethnographic methods to uncover processes and interest relations that lead to the concurrent formation and reformation of local-global relations at every level. In other words, to fully understand how relations are produced and reproduced, and the interests that underlie those processes, it is important to observe the daily interactions of actors

\footnotetext{
1 The literature on world-systems analysis and its processes of incorporation and peripheralization is vast. For a useful summary, see Wallerstein (2004).
} 
who are involved in them. Here, ethnography, along with documentary and other data, is a key resource of critical political economy because it helps us understand how the interests of core and peripheral actors are realized or blocked.

An ethnographic approach to the critical political economy of the EU-Turkey relations that culminated in the common customs arrangements suggests that hegemony is negotiated in a bureaucratic political configuration, where resistance from the periphery to core hegemony is palpable in the wider European region. But a proper account of the critical political economy of the EU-Turkey economic integration cannot be attained if scholars insist on the arbitrary agenda of seeing political economy devoid of political culture, and political culture insular from political economy, much like Chalfin's (2010:44) following prognosis:

A fully anthropological approach to the state equally recognizes that sovereignty is deeply entangled culturally as well as socially and involves the production of meaning and ways of being and knowing. Such a cultural orientation offers an important alternative to more strictly political economic approaches which privilege the instrumental over the experiential dimensions of state authority and hence fail to address the fundamentally ideological character of sovereign power and its transformation.

Unlike Chalfin, and following Polanyi (1957) and Hopkins (1957), I contend that a critical analytical account of power should focus on the embedded relationship between political economy and (political) culture (also see Hertz 1998 for a similar argument).

Many students of European integration used the transnational encounters of people who manage the everyday running of the EU's techno-bureaucracy as a "laboratory" to study the localized trajectories of global/regional integration, to see whether an emergent "common European interest" (Bellier 2000:56; Abélès 2000) could replace national identities, interests, and preferences. In today's Europe, common interest formation in many areas of life is largely enabled by the EU's gigantic techno-bureaucracy, which anthropologists and ethnographers have long studied. Studying the role of policy-workers such as bureaucrats and consultants in policy processes, some anthropologists suggested that researchers focus on the "ritual[s] and [the] production of meaning" in these processes "rather than [the] production of effective policies per se" (Blom Hansen and Stepputat 2001:17). For others, bureaucracy is as "an emotive domain" that "produces and incites specific modes of affectivity in its own right" (Navaro-Yashin 2006:182; also see Herzfeld 1992; Graham 2002; Alexander 2002 and Stoler 2004). In both cases, bureaucrats, consultants, and other policymakers are viewed primarily as meaning-producing actors and agents, thereby cultural performers, "whose product should not be judged in terms of its supposed practical ends" (Stirrat 2000:43; see Herzfeld 1992 for an original contribution along similar lines).

Yet, scholars tend to think of the work of public officials, the end result of their work, and the social contexts within which they come to work, as independent phenomena. This wrongly suggests that the bureaucratic domain is insular from other realms of economic and political life and a place where legitimacy emanates from within. In fact, it is imperative to study the symbolic dimension of bureaucratic 
work (done by bureaucrats or by others) and the practical policy results of such work at the same time. This is simply because if bureaucrats act as cultural actors, then they act in a cultural environment, which ultimately shapes and is shaped by their actions. Just as Polanyi (1957) and Hopkins (1957) argued that economic actions are embedded in social life, so too are bureaucratic and political actors and institutions. More importantly, if bureaucratic actions are taken as independent of their environment (i.e., their immediate and wider bureaucratic culture), it becomes impossible to establish accountability. Yet again, it is important not to take these wider bureaucratic cultures at face value but to contextualize their dynamic natures. Here, unequal power relations between Turkey and the EU, I argue, inform not only bureaucrats' encounters with each other, but also their own policy work, wherein Turkish officials demand collocution and immediate and equal representation, and the Commission officials deny their demands due to the ways in which the EU negotiates with candidate countries, and also because of the two sides' competing political economic interests.

For those who take bureaucracy as a social institution, "an understanding of bureaucratic work requires the analysis of social relationships between officials, between officials and clients, and of more inclusive social fields within which contacts and relationships are played out" (Handelman 1978:9). ${ }^{2}$ The following discussion on the social relationships of Turkish and EU officials suggests that such relationships are both constituted by and constituting bureaucratic actors' capacity to bring outside and in-group influences into their encounters with counterparts from the supranational level. As in every political act of instituting, their ways of doing this have manifest and latent symbolic qualities, not least the rites and rituals of institutions (Bourdieu 1996, 1999). In pointing to the relationship between power and its dramatic manifestations, Cohen (1980:66) suggested that "ordinary symbolic performances as a dancing ball, a university graduation ceremony, a funeral service or a wedding festivity repetitively reproduce or modify power relations" (also see Kertzer 1988). Following these strands of scholarly inquiry, I take bureaucratic encounters between officials who are party to the EU-Turkey Customs Union as symbolic performances that are also constitutive of cultural and political relations in negotiations of economic integration, and thus in return heavily influence those economic negotiations and the definition of economic interests of both sides. Due to failed promises of political integration and discomfort with the existing provisions of the EU-Turkey Customs Union, Turkish politicians, officials, and businessmen are looking for other ways and means to broaden their space for political maneuver and their capacity to regaining political economic sovereignty vis-à-vis the EU. Close encounters of officials within this framework carry unique insights into the actually lived process of interest formation and the day-by-day development of what matters most in the EU/Turkey agenda.

\footnotetext{
${ }^{2}$ For anthropological and other ethnographic studies of the EU-building that paid special attention to Eurocratic encounters between officials from national governments and the EU institutions whether they took place in Brussels or in EU member states, see Abélès (1992); Abélès et al. (1993); Bellier (2000, 2002a, b); Geuijen et al. (2007, 2008); McDonald (1996, 2000); Muntigl et al. (2000); Shore (2000, 2002, 2007); Shore and Black (1994); Shore and Baratieri (2006), Thedvall (2006, 2007); Wodak (2009).
} 
When the EU-Turkey Customs Union was first envisioned in the 1960s, the idea of political regionalization in Europe was less pronounced than today. By the time it went into operation in 1996, European economic integration coupled with political consolidation in the wider region was already experiencing its second coming with the fifth enlargement of the EU and the accession of former socialist countries. At that time, Turkey had been experimenting with free market mechanisms for over a decade, having launched a transition from protectionism to export-oriented industrialization in the early 1980s. After more than 15 years in existence, however, the Customs Union faces acute problems. I argue that these problems are due to growing frictions between Turkey and the EU, which correspond to discords in forming common economic and political interests in a number of areas of cooperation. As communicated to me by EU and Turkish officials entrusted with facilitating the customs regime, discussed in great detail below, the Custom Union's apparent mismanagement and distortions are a manifestation of a disjuncture in the formation of common interests regarding the overall objectives of economic integration between Turkey and the Union, a disjuncture that is marked by unequal power relations. As a result, dramatic expressions of state power have entered this process, especially from the Turkish side, in order to remedy (or cover up) its perceived power deficit with respect to the EU. Such bureaucratic dramas exacerbate Turkish officials' disintegration from joint agreements with their EU counterparts. Appearing as bureaucratic inertia, such disintegration effects have implications for membership talks, with the Turkish officials at individual and collective bureaucratic levels experiencing loss of control during negotiations with EU officials. As can be traced from transnational day-to-day encounters of techno-bureaucrats working on customs issues, this process in turn put the future of economic integration at risk.

\section{Economic gains and political losses: introducing the EU-Turkey Customs Union}

In 1951, European leaders brought together French coal and German steel-along with four other western European countries - to establish the European Coal and Steel Community. They thus instituted economic cooperation as a model for resolving political feuds that resulted in two devastating wars in the region and beyond. As part of a long-standing common market initiative for greater economic integration in the wider region, they then established an economic community in 1957 with the Treaty of Rome. Emphasis on "community" was more pronounced than in economic cooperation models that existed elsewhere. Partially modeled upon the German Zollverein (see Henderson 1981), the Treaty of Rome prescribed a common customs union whereby processed goods could circulate among member states without tariff and customs duty barriers. Today, 31 countries participate in the European Customs Union, including 27 EU member states plus Andorra, San Marino, Monaco, and Turkey.

The biggest economic benefit from participating in the common internal market is the ability of a member state to trade freely within the area as long as it observes common rules. The biggest disadvantage is that it cannot protect its producers from 
outside competition, particularly from giant core EU companies or from US and other transnationals producing in or exporting to the EU. Turkey has been in an awkward position since it signed an agreement of customs union with EU member states in 1996. It remains the only country that entered the Union before it even acquired candidacy for EU membership, which came in 1999 (Eder 2001:33). Since 1996, trade between EU countries and Turkey is free of duties and tariffs, and all apply common tariffs on imports from third countries. The customs union mandates free movement of industrial goods and processed agricultural goods between Turkey and the EU by eliminating customs duties and quotas; products such as nonprocessed agricultural goods and steel are exempt but are covered by separate agreements. This provision of "no customs on industrial and processed agricultural goods" covers goods that are wholly produced in Turkey or in the EU but also those that are imported from third countries and reexported after being processed in Turkey or in the EU. ${ }^{3}$ Customs union thus means a comprehensive regime of internal economic "deregulation" whereby the EU effectively regulates a participating country's economic and social policies on labor and employment, intellectual property rights, and so on.

The establishment of competition rules, common trading policy, and the conclusion of international agreements are issues on which common EU decisions prevail over the interests of individual member states. Such common decisions are initiated by the European Commission, the executive body of the EU, and are then negotiated in the European Council and European Parliament. When the Turkish government hired lobbyists from prominent global public relations companies to run a campaign for a EU-Turkey Customs Union in Brussels, it aimed for a greater, yet distant goal: full EU membership. ${ }^{4}$ Consultants from the Brussels office of the New York-based Hill and Knowlton successfully reached out to members of the European Parliament (MEPs) and EU member governments via their representatives in the Council, in order to show that the Turkey-EU customs union was "safe" for Europe. ${ }^{5}$ At the time, EU parties such as the German Christian-Democrats supported Turkey, contemplating that customs union would be enough. Yet, their Turkish counterparts hoped for more (see Kramer 1996). Following ratification of the customs union by the European and Turkish parliaments, Turkish school children received the good news as the voice of their schoolmasters poured from classroom speakers: "As of today [1 January 1996] our country has entered into a customs union with the EU. Congratulations to our nation. May it bring prosperity to all of us!"

\footnotetext{
3 See, DG TAXUD_Turkey: Customs Unions and preferential arrangements_-General introduction, http://ec.europa.eu/taxation_customs/customs/customs_duties/rules_origin/customs_unions/article_414_ en.htm.

4 Interviews with a consultant (March 13, 2009, Brussels) and a former trainee (June 2, 2009, Brussels) from Hill and Knowlton, both of who had worked on the Turkey-EU customs union campaign at the time. The Turkish government had hired another lobbying company in Washington to lobby the US government in order to get them lobby the EU publics. The Turkish government's efforts resulted in the US Mission to the EU in Brussels and US embassies in big member states mobilizing their support at the EU level.

5 Interview with a Hill and Knowlton consultant (March 13, 2009, Brussels).
} 
Fifteen years later, the European Commission asserts that Turkey has greatly benefitted from the customs union:

Turkey has benefited from an "early" legislative alignment process before its accession negotiations started. Turkey is participating in the EU single market for goods. Turkey has been implementing a EU-aligned anti-trust legislation for 10 years. Turkey has benefited from an almost EU-aligned customs legislation for 10 years. Turkish exporters are experienced in manufacturing according to EU technical standards. Turkey has adopted and implemented many intellectual property rights. ${ }^{6}$

Indeed, for some Turkish manufacturers, customs union meant that their washing machines marched into EU markets. The trade volume between Turkey and the EU in 2009 was more than five times that of 1995. Meanwhile, between 1996 and 2009, the share of agriculture and of textiles and clothing in Turkish exports to the EU fell by half, while the share of automotive sector, machinery, and iron and steel increased five-, three- and two-fold, respectively. In 2009, $75 \%$ of Turkey's automotive exports, $69 \%$ of textile and clothing exports, $54 \%$ of electronic equipment exports, and $51 \%$ of machinery exports were directed at the EU. The main European export destinations from Turkey in 2009 were Germany, France, UK, Italy, and Spain, while Turkey's main EU import partners were Germany, Italy, France, Spain, and the UK (in decreasing order of export and import volumes). ${ }^{7}$ In 2010, the EU accounted for $46 \%$ of total Turkish export and $40 \%$ of total import volumes. ${ }^{8}$ Trade volumes always provide favorable figures for those who support Turkish membership in the EU. But they do not address issues of developmental imbalance where, for example, a high proportion of Turkish machine exports are reexports by transnational corporations of parts and materials that were imported into and assembled in Turkey (Yilmaz 2007:246). Such trade quadrupled in the last 30 years as the country moved away from import substitution (Kirisci and Kaptanoglu 2011:705).

The growing share of manufactured goods in Turkey's exports led some analysts to acclaim the country as "Europe's BRIC" or "the China of Europe" (The Economist, 21 October 2010). Yet, from the Turkish perspective, the Customs Union strikes many as a failed experience, particularly because of inequalities between EU member states and Turkey in economic development, hence, in market competitiveness. A medium-sized Turkish businessman explained to me his frustration with the existing parameters of the customs union in the following way:

They [potential buyers from certain sectors in the EU] come to us and tell us to produce such and such product according to such and such regulations and

\footnotetext{
${ }^{6}$ http://www.avrupa.info.tr/AB_ve_Turkiye/Gumruk_Birligi.html.

7 See "Trade Relations between Turkey and the EC," prepared by the Directorate-General for European Affairs, Undersecretariat of the Prime Ministry for Foreign Trade. Online available at http://www.dtm.gov.tr/dtmadmin/upload/AB/ABKurumsalDb/trade.doc.

${ }^{8}$ See "Turkey-EU Bilateral Trade and Trade with the World," prepared by the Directorate-General for Trade (DG TRADE) of the European Commission, March 21, 2012. Online available at http://trade.ec.europa.eu/doclib/html/113456.htm.
} 
product model. They tell us how much they will pay us for the product. They dictate their own experts as controllers during the production process. They even demand their own trucks to transport the finished products to designated addresses in the EU. There is greater industrial production in the EU but no one to drive the trucks [to transport goods around]. For the EU, Turkey is the Near East [compared to China being Far East]. They need human labor; skilled human labor; labor of those who are like them. ${ }^{9}$

On the other hand, big businessmen in Turkey seem to enjoy being called the China of Europe for the exact reasons that upset this businessman, that is, in hopes of attracting more foreign investment. ${ }^{10}$

Even from the beginning, however, customs union with the EU meant more than simple regulatory changes and short-term economic benefits for Turkish political and bureaucratic elites and the bourgeoisie. It meant a step toward EU membership, which they valued very highly. Membership would enable them to participate in EU decision making about economic matters that have regional and global reach. Turkish elites, who ratified the customs union agreement despite strong domestic dissent, often couched as anti-globalization sentiments (Eder 2001; Ülgen 2006; Ülgen and Zahariadis 2004; Yilmaz 2007), argued that further economic integration with the EU could bring eventual political union. Once the customs union agreement was in place, they said, the famous "spillover" effect would kick in and complete the job. Major theories, projections, and promises of EU integration pointed this way. As Ernst Haas, one of the ideologues of European integration, once suggested, "the essence of supranationality lies in the tendency for economic and social decisions to 'spill over' into the realm of the political, to arise from and further influence the political aspirations of the major groupings and parties in democratic societies" (1964:65). Partially in justifying the supranational decision making whereby national sovereignty is pooled into a supranational governance system as a result of economic globalization (Sassen 1996; Keohane 2002; also see Ong 2000 for pooling of sovereignties in extra-European spaces), Haas (1964:65) further contended that "the indirect penetration of the political by way of the economic" is a necessary evil because "the 'purely' economic decisions always require political significance in the minds of participants." Today, the EU-Turkey Customs Union is still in place, but expectations from the Turkish side on using it as a means for pushing EU leaders to grant full participation in the legislative and political life of the EU have waned, along with the necessary collegiality from the EU side such an act would require. ${ }^{11}$

\footnotetext{
9 Personal communication with a chemical engineer working in the pharmaceuticals sector (September 20, 2010, Istanbul).

${ }^{10}$ Sureyya Ciliv, the CEO of Turkcell, and Tugrul Kutadgobilik, the chairman of the Turkish Confederation of Employer Associations (TISK) both speaking at the "Opportunity of Enlargement to Europe: Turkey," a working session organized by Turkcell during the European Business Summit held on March 26, 2009 in Brussels.

11 From a statistical perspective, Turkey's foreign trade with the EU seems in gradual decline, but this is due to the global financial crisis (Kirisci and Kaptanoglu 2011:715). Nevertheless, Turkish businessmen are now also eyeing on alternative markets in neighboring regions such as in Africa and the Middle East, and in Russia, with their politicians helping them by brokering politically favorable business environments.
} 


\section{Frictions in common interests and the problem of representation}

In recent years, Turkey and the Commission have quietly raised objections regarding existing provisions of the customs union. According to the terms set by these two parties in 1996, Turkey agreed to join the already existent common customs area. This simple legal fact, however, is not so simple in the world of political economy, including the European economic zone, where national interests still cause great discord, conflict, and bureaucratic battles between parties to this common regime.

The Turkish side claims that when the Commission on behalf of EU member states signs free trade agreements (FTAs) with third countries, they must individually sign similar FTAs with Turkey (which they are usually reluctant to do) in order for the EU-Turkey Customs Union to apply to these countries. An FTA is a legal economic framework under which "two or more countries minimally agree to eliminate tariffs, quotas, and preferences on most traded goods. Most FTAs today also seek to liberalize trade in services, investment, and numerous other regulated areas of economic activity. At the same time, members of an FTA maintain their own tariffs, quotas, and other non-tariff barriers vis-à-vis nonmembers" (Ahearn 2011:1, n.1). Hence, when goods from third countries enter the Turkish market without paying any customs duties, the same does not automatically hold for Turkish exports. Turkish representatives to the Customs Union Joint Committee (CUJC) ${ }^{12}$ meetings held in 2008 and 2009 repeatedly asked the Commission to consider Turkey's interests and to inform Turks about common EU positions before and after the signing of new FTAs with third countries (Ülgen and Zahariadis 2004:7-8).

During the 20th CUJC meeting - as the representative of Turkey's most powerful business lobby then based in Brussels reported-the Commission representatives stated that Turkish representatives of public interests could participate in relevant committees and working groups when and if Turkey harmonizes its laws according to the Commission directives on the relevant area; participation in comitology committees (see below) is not possible when neither full harmonization nor membership is in sight (TUSIAD 2008a:10, b). A year later, the Turkish side brought FTAs onto the joint committee meeting's agenda once again. This time, the Turkish delegation asked the Commission to make sure that the existing and upcoming FTAs with third countries covered Turkey, too. They recommended that the Commission add a "Turkey clause" to future FTAs. ${ }^{13}$ Otherwise, they claimed,

\footnotetext{
12 The customs union agreement went into force on July 1, 1996, upon ratification in the national parliaments of EU members and Turkey. A committee to ensure its proper functioning was subsequently established. The EC-Turkey Customs Union Joint Committee (CUJC) thus provides a common platform for officials from both sides to meet regularly and discuss issues directly pertaining to the technical functioning of the customs union. Cochaired by one representative from each side, the CUJC now meets once in six months, although it was initially envisaged to meet once a month. These meetings are exclusive gatherings with restricted access. Here, I rely on minutes of the meetings kept by a consultant based in Brussels who regularly attends on behalf of Turkey's main representative body of big business.

13 Ülgen and Zahariadis (2004:9) noted that the Commission invoked such a clause in the draft free trade agreement with Vietnam. But the issue remained unresolved since the matter repeatedly came up in subsequent CUJC meetings as we learn from the minutes of meetings from 2008 and 2009 to which I refer here.
} 
Turkey would take necessary measures to protect itself. The Commission responded that, although any FTA the EU signs with third countries are by default extended to include Andorra and San Marino, Turkey is a major competitive power unlike these two countries and that the EU cannot negotiate FTAs on behalf of Turkey with third countries within the exiting institutional structure, that is, without Turkey's EU membership (TUSIAD 2010:1).

In fact, until Turkish EU membership is finalized, companies from both sides trade in uncharted territory. When Turkey takes measures to "protect its interests" by curbing access of non-Turkish companies to its markets, these companies go to the permanent representatives of their originating country in Brussels and to the Commission to raise complaints. When Turkish companies experience restrictions in doing business in EU member states, however, they cannot do the same. Even when they go to the Commission, which they often do, it advises them to take their case directly to the governments of EU member states involved in the dispute. ${ }^{14}$

The Commission is in an awkward position vis-à-vis Turkey with regard to its representation of EU member states and its brokerage of common interests between them and candidate states. Minutes of the CUJC meetings attest that Turks continuously try to get the Commission to represent them-as if it is a state agency of either Turkey or the EU-by demanding that it act as a go-between for Turkey, EU member states, and third countries. Such calls are not always rejected outright, and the Commissioners could help solve such matters for candidate countries. But this is exactly the moment when a seemingly simple technical matter of economic loss turns into a matter of political representation, which requires the Commission to act on Turkey's behalf as a result of its political demands.

The main fault line of the EU-Turkey Customs Union is political. Usual EU practice suggests that candidate countries enter a customs union with the EU after they become Union members, that is, political integration precedes economic integration. But the Turkish case is an anomaly because a customs union did not lead to political integration in the form of EU membership. One critic described the EU-Turkey Customs Union agreement as "living in sin" (Peers 1996). Not only did enhanced economic relations not spill over into the political domain, failed experiences in economic integration actually smothered hopes for the possibility of political integration in any near future. In return, some negatively affected groups (mainly from Turkey) began circulating rumors that put into question the overall benefit of remaining in the customs union.

From the Commission's perspective, the customs union brings both rights and obligations. In particular, Turkey was expected to make a number of changes to its trade and technical laws in order to harmonize with EU legislation. This became a problem. According to an EU official who has first-hand access and knowledge,

Turkish authorities were arguably not encouraged by a number of other factors that negatively affected their ability to effectively align their technical legislation with the EU's. For political reasons the EU, which had taken more than a year to communicate the list of instruments to Turkey, did not deliver

\footnotetext{
${ }^{14}$ Interview with a Commission official (March 19, 2009, Brussels).
} 
the aid announced as part of political deal surrounding the $\mathrm{CU}$ [customs union], whereas Turkey lacked expertise and needed technical assistance to adopt, implement and enforce acquis-compatible legislation. (Misrahi 2010:196)

This should not come as a surprise, however, when even the EU's common law (the acquis communautaire) itself becomes at times a means for politicization in TurkeyEU relations.

In the final analysis, the customs union envisages a comprehensive framework for Turkey's trade relations and economic policies. Without "enjoying" full participation in the decision making of these policies due to lack of EU membership, Turkey tries to protect its economic interests by requiring duplicate procedures for imports that are already certified in Turkey/EU trade or by putting restrictions on imports of goods from third countries that are in free circulation in Turkey/EU (for a discussion of some of these trade restrictions, see Misrahi 2009). A decade into the customs union, one of its negotiators complained that,

Turkey continues to lack the technical capacity and infrastructure to fully meet the needs of the testing and certification process. The most serious problems appear to be concentrated in the crucial areas of metrology and calibration, quality certification and laboratory testing. Such lack of infrastructure in turn translates into a lack of confidence in Turkish processes and procedures. In effect, the resulting burden for Turkish exporters has become significant, as they need to certify their products with foreign laboratories and institutes, which in turn means increased transport and other administrative costs. (Ülgen and Zahariadis 2004:16)

Soon after, Turkish authorities began to request similar certificates in order for the EU products to enter into the Turkish market. Technically,

these certificates attest to the conformity of products originating in a member state or [a partner country] to the legislation applicable to that product. Between the EU and a third country ... the recognition of such certificates means that, when the certified product exported by a member state or [a third country] reaches the [third country] or member state of destination, it should not be subject to double testing, unless the country of origin has serious doubts as to the products safety ... [because otherwise] market access risked being impaired due to non-recognition of conformity certificates. (Misrahi 2010:190)

In the absence of trust and confidence-a theme run amok in recent relations between Turkey and the EU manifest in many policy fields-both parties use "technical" means to protect their interests (COM(2009)533 (SEC(2009)1334):5; Ülgen and Zahariadis 2004:14), even when it may dilute the customs union by not implementing it in full capacity and thus going against the spirit of customs union, bilateral trade agreements, and trustworthy partnership. ${ }^{15}$

\footnotetext{
15 Interview with two Commission officials from DG AGRI (April 9, 2008, Brussels).
} 
The establishment of mutual trust and confidence, however, are cultural matters. The apparent distortions and mismanagement in the EU-Turkey Customs Union, manifested as latent economic protectionism in trade relations, can thus be interpreted as a means for both sides to manage the political and economic costs associated with Turkey's EU accession process (Misrahi 2010). Such protectionism is not only observable in economic or political terms. It has important implications at the personal bureaucratic level, manifest in the cultural behavior of the very actors and agents of this process. So, let us examine such behavior and practices.

\section{Short-range passes on a narrow field: bureaucratic encounters within the framework of the EU-Turkey Customs Union}

The Commission has been an active engineer, negotiator, and promoter of a common European identity-interest (Laffan 1996, 2004; Shore 2000). Economic frameworks such as customs unions that engender greater integration in policy toward third countries are a means through which common interests are formed and operate. According to March and Olsen (1998:967), the EU provides "numerous arenas for interaction, argumentation, and collective problem solving and conflict resolution for bureaucrats, experts, representatives of organized interests, and elected politicians." Embedded in this learning process is a socialization effect, whereby such meetings provide fertile ground for common European understandings to emerge during policy processes wherein participants are exposed "to new arguments, new perspectives, and new identities," and whereby they develop "capabilities for mutual engagement" (March and Olsen 1998:967). Therefore, in such meeting settings,

considerable experience with acting together is accumulated, and a significant amount of mutual influence between the EU and domestic institutions and actors is taking place, with no clear-cut borderline between the "national", and the "European." The number of meetings in the context of the EU, together with meetings in the context of other international institutions, during some periods actually makes ministers, bureaucrats, and experts interact as much with colleagues from other countries as with their domestic colleagues. (March and Olsen 1998:967)

One common depiction of Europeanization in political science, sociology, and anthropology is to regard such socialization effects as "national adaption" (Harmsen and Wilson 2000:14). According to this common definition, Europeanization as national adaption refers to a process through which "EU institutions and politics affect member states' institutions and policies" (Beyers and Trondal 2004:919; also Kassim et al. 2000, 2001; for a critique, see Harmsen 1999). Defined in this way, Europeanization cum socialization at the supranational level can also work as "an 'action trap' in which agents, once set on a specific course of action, find themselves obliged to take a set of further actions that point them in a direction in which they did not necessarily intend to go" (Abélès 2002:242).

Commission officials regularly meet with representatives of public and private interest groups from candidate countries. To extend EU norms and values to 
candidate countries during the accession process, the Commission customarily implies, expects, and at times demands that candidate country representatives gradually become part of this working environment and adapt to its norms and forms. In this regard, common interest formation can be a corresponding process to socialization at the EU level, brought by the EU's specific engagement with candidate countries, which is more pedagogical than collegial in nature (Bellier 2004; Schmid 2004; Teivainen 2009). What follows is a thick account of bureaucratic management of the negotiations of terms and conditions of the TurkeyEU partnership in customs and other associated areas, which reveals the political and cultural imagination of joint futures by both parties-or the conditions that produce their absence. I describe bureaucratic encounters of officials from both sides. The larger political economic context and its associated fissures that surround such encounters by and large eclipsed bureaucratic work on the customs union and ensuing cultural encounters between actor and participants. Yet, as I have argued, the cultural-political framework has crucial impact on the creation of political economic processes.

Within the framework of the EU-Turkey accession negotiations in which the customs issues frequently figure, the Commission officials and their Turkish counterparts encounter each other in various technical meetings, sometimes as frequently as once a month. Turkish public officials attend accession meetings as representatives of Turkish "national interests"-however complex they may be (Lewis 2009)—whereas the Commission team purportedly represents the "common European interest" of 27 member states (Abélès and Bellier 1996). The Commission's privileged role of initiating laws via Eurocratic input is crucial in representing common community interest(s) during accession negotiations, especially because it has a vast pool of expertise and tactical maneuvers (Page 1997:154). The Customs Union Joint Committee meetings I mentioned above, for example, are only one variant where intense negotiations of this sort take place. The Turkey-EU common customs regime is part of Turkey's EU accession negotiations because candidates must fully comply with the legal provisions of customs union under EU law for the accession process to proceed toward membership but also because the common customs regime incorporates EU policies on taxation, intellectual property rights, trade, and industrial policies, among others.

The Commission's direct counterpart in Turkey is the government in Ankara. When it negotiates with candidate countries, the Commission acts like the "government" of the EU, despite the fact that it is not a state in the classical sense of the term (Shore 2006) and there is no "European citizenry" on whose behalf such a super government could act (cf. Déloye 2000; Meehan 2000; Neveu 2000; Shore 2000). However, with its executive organ acting like a government under legal mandate, especially during its dealing with third countries, the EU has increasingly become a quasi-state, formed not by democratic but by technobureaucratic politics.

Separate directorate generals in the Commission do daily business with their Turkish counterparts from fifteen ministries and numerous state agencies. After years of dealing with Turkey in the context of its smothered embryonic candidacy, after attending numerous meetings with Turkish delegations, and after participating 
in missions and field trips, ${ }^{16}$ many Commission officials have a common assessment of the Turkish bureaucracy. My interlocutors from the Commission's 19 directorate generals (39 Commission officials participated in this research) described Turkish bureaucratic culture as hierarchically organized, wherein the organizational hierarchy thickens as one moves upward. According to their observations, this results in a vertically challenged communication between higher-ups and lower level officials from either side. Over and over, my interlocutors from the Commission suggested that there was a difference in their relations with Turkish counterparts between formal (rigid, indirect, hierarchical, and procedural) communications and more informal (direct) ones. In terms of practicality, Commission officials working on Turkey preferred to be in direct contact with their Turkish counterparts from various ministries in Ankara. In Turkey, the responsible unit for coordinating customs affairs is the Turkish Ministry of Customs and Trade. Accession negotiations are by and large coordinated by the recently instituted Ministry of EU Affairs, which remains under the strong shadow of the Ministry of Foreign Affairs. Other agencies such as the Office of the Prime Minister and the Ministry of Economy also often try to increase their voices in customs policies and decision making.

The Commission officials from other directorate generals-which are known as line units and function like regular ministries in national state systems though with high number of expert officials among staff-are expected to pass their information requests to the Directorate General Taxation and Customs Union (DG TAXUD), the main Commission authority supervising the EU-Turkey Customs Union which also organizes joint customs committee meetings. DG TAXUD refers all requests of information, appeals, and complaints to Turkey's official delegation to the EU in Brussels, which follows the chain of hierarchy in bureaucratic communication between the Turkish offices: from Turkey's EU representation in Brussels, to the foreign affairs ministry in Ankara, and only then to the respective line ministry. This long chain increases time and energy spent on communicating between partners, especially when official communication channels are not working properly due to political competition between Turkish ministries and state agencies (Keskin 2002). Equally, when some individual bureaucrats are sent to work at Turkey's EU representation in Brussels, they are stripped of their technocratic features and become mere diplomat-bureaucrats, thus encountering a greater risk of being cutoff from negotiations with the EU. To prove public ownership of the EU-Turkey relations by various state offices and agencies, something demanded by Turkey's prime minister himself, resistance by some of these Turkish officials to otherwise easing the Turkey-EU administrative communication is thus very meaningful: It helps some officials to reemphasize their role in EU negotiations but most notably their role in Turkey's domestic bureaucratic politics. ${ }^{17}$

\footnotetext{
16 There are also those few who had been assigned to Turkey as seconded national experts by way of the twinning program and other bilateral administrative cooperation schemes for short-term stays.

17 For a discussion of bureaucratic politics in terms of environmental policymaking within the framework of Turkey's EU accession, see Unalan and Cowell (2009).
} 
Meetings between Commission officials and their Turkish counterparts bring about a mutual learning process. Over many years of accession negotiations, participant-actors from both sides learned (and still learn) how to deal with each other. Such learning cannot be thought outside a pedagogical framework with emphasis on mutual learning and teaching wherein participants negotiate with each other as much as they learn how to negotiate. Earlier in the long history of institutionalization of Turkey-EU relations, the Turkish government sent high-level officials to meetings with the Commission. This changed, however, once the government realized that the primary objective of such meetings is simply to exchange technical information.

Other than technical and sectoral meetings on the customs union, the Turkish and Commission officials have numerous occasions to encounter one another during comitology committees and the Commission's working groups. There is a comitology committee wherein FTA-related issues are talked about, and Turkey wanted to be a party to this committee for reasons I discussed above. In EU jargon, comitology committees refer to proto-decision making platforms that

assist the Commission in executing its implementing powers by giving an opinion on draft implementing measures before they are adopted. They include representatives from each EU country and are chaired by a Commission official. They also act as a forum for discussions on implementing measures, and a channel of communication between the Commission and the national authorities. ${ }^{18}$

These comitology committee meetings are thus vital to attend for anyone who has a stake in participating in the EU's policy and decision making while ideas are in formation. The Commission recently began inviting Turkey to some meetings as an observer, especially those on automotive and textiles sectors, in which Turkey is an important producer and exporter to the EU. But comitology work on different aspects of Turkey's EU accession is still very limited. Turkish representatives travel to Brussels for these meetings without voting at the end on texts that carry the Commission's opinions. One Turkish official who worked in Brussels at the time of our interview and who participated in one such meeting described it in the following words:

It is like an intra-family meeting. You feel like you entered their bedroom. Twenty-seven of them [member states' representatives] sit in these meetings. Twenty-seven [representatives] of the member states are speaking to each other calmly and properly. It affects me a lot. They call each other Mr. Germany, Ms. UK. They have a serious tradition of consensus and cooperation. Twenty-seven people-states sit down and talk about issues down to minute detail, and they talk openly/freely. ${ }^{19}$

\footnotetext{
${ }_{18}$ See http://ec.europa.eu/transparency/regcomitology/index.cfm?do=FAQ.FAQ, accessed on December $15,2011$.

19 Interview with an official from the Permanent Delegation of Turkey to the EU (May 29, 2009, Brussels).
} 
A sort of embarrassment was triggered in this Turkish official's immediate thoughts and feelings as he encountered the EU bureaucracy. He felt like an outsider in a place where he did not belong, as if the gathering was only for family members. Here were two processes of othering operating in tandem: one side othering the EU bureaucracy vis-à-vis its own (Turkish) bureaucracy, and the other internally othering the Turkish bureaucracy as the anti-character to itself (with the official's double reference to talking "calmly" and "openly").

Officials frequently use stereotypes when they talk about each other, stereotypes that are refined by many years' encounters. Such stereotypes as currencies of cultural encounters prove bureaucracy to be a social institution. One such stereotype was invoked by a British Commission official during our interview at his DG's cafeteria, as he described the culture of governing in Turkey. His account includes both self- and other-portrayals. The account is comparative by default, for comparativism is after all deeply embedded in the very logic of EU governance and membership negotiations.

To compare the politics of bureaucracy and bargaining among and within EU member states and candidate countries, the Commission official distinguished between courtier and college systems. ${ }^{20}$ In the college system, various governmental ministers sit around a table with their counterparts from the Commission and talk about problems in a policy area. Each has an equal say. From this Commission official's almost stoic perspective, the main objective of this sort of meeting is "to solve social and economic problems by way of public policy." Officials attending these meetings come up with working plans by means of mutual agreement. In the college system - this official gave Germany as an example - there is "compromise" and "cooperation" for the common cause between governmental and political actors. The courtier system, to the contrary, rests upon high concentration of power and authority in individuals who sit at the top of the political structure. Elite outsiders may manipulate the system, but they do not have a seat at the table. ${ }^{21}$

My Commission interlocutors en masse observed that the Turkish side attends technical meetings as a crowd. The size of the Turkish delegation may vary, but no less than 40-80 people are present in technical meetings held with the Commission, representing all governmental ministries and state agencies that are involved in one policy area, especially if the meeting is held in Turkey. Meetings with the Commission constitute a learning experience for Turkish delegates, who may also see these meetings as a rare opportunity to travel abroad. When meetings are held in Brussels, they are welcomed by a smaller Commission delegation of about 5-6 officials.

During the meetings, group membership is clearly distinguishable; so are the interests each group represents. According to which interests they represent, officials take seats facing their counterparts from the rival team. This and other Commission interlocutors suggested that candidate country representatives usually

\footnotetext{
${ }^{20}$ Interview with a Commission official (May 25, 2009, Brussels).

21 "Courtier" is a term first used in the 14th-century Renaissance Italy to describe those "in attendance at a royal court" and those "who practice flattery," usually in order to get something or to win favors. Merriam-Webster Online Dictionary-Entry on Courtier, available http://www.merriam-webster.com/ dictionary/courtier. Accessed on August 25, 2010.
} 
have leeway to influence the atmosphere in which technical negotiations take place. The sitting order gives clues about the ensuing style of negotiation and ultimately the "culture of compromise" (Abélès and Bellier 1996; Bellier 2000; also see Sideri 2005), or the lack thereof, between officials from both sides, something that my Turkish interlocutors also mentioned.

Unlike Croatian Eurocrats, who tend to socialize during technical meetings, Turkish officials sit together as if they are lining up for an upcoming battle or a penalty kick in a football game. ${ }^{22}$ When asked to comment on different behaviors of Turkish and Croatian bureaucrats, one Turkish official with two-year's experience with the Commission suggested that it is wrong to compare the two: "We [Turkish bureaucrats] have a state tradition.... We would never buddy-buddy [kanka olmak] with the Commission [as Croation officials do], even if Turkey might soon become a member state." ${ }^{23}$ Of the seven Turkish officials based in Brussels (there are 26 in total) who participated in this study, three explicitly referred to Turkey's "state tradition" as the main factor that impedes the country's progress toward accession, and which distinguishes it from other candidate countries. Trade negotiations are especially significant in this context. A Spanish Commission official gave the following example when we were discussing problems associated with trade negotiations over processed agricultural goods that are covered by the customs union:

They [the Turkish government] don't give me sellable arguments ... You don't have to surrender, you find and accept a generous solution ... stay calm and concentrated; just give the data. Be cool in debates. [But] they [Turkish officials] lose their temper. Don't go to the poetical game, because you [Turkish officials] are going to pay there! It's not free of charge to get tomato quotas; you [need to] give us fiscal data... The Community is not a heaven; consensus is not without a pay. Generosity, welfare... you [Turkey] need to care about other(s); respect others with care. ${ }^{24}$

Clearly, from the perspective of this Commission bureaucrat, Turkish officials see negotiations as an opportunity for "give-less and take-more," without surrendering points to the opposing team. Some Turkish officials agree apparently because concession-makers run the risk of looking weak or of losing control of negotiations altogether. One Turkish official recounted a colleague who, returning from a technical meeting with the Commission, bragged to his seniors in Ankara about his "victory over the Europeans." 25 Yet, it is also a cultural fact that "negotiation" and

\footnotetext{
22 Interview with Commission officials (9 April, May 25, 2009, and June 2, 2009, Brussels).

23 Phone conversation with a Turkish official from the Ministry of Economy (August 2, 2012).

24 Interview with a Commission official from the DG Enlargement (December 18, 2008, Brussels). The "tomato quotas" this official was referring to are export quotas the EU applies to Turkey on tomato paste. Since 1998, the EU is not allowing Turkey to utilize its 38,400-ton duty-free tomato paste export quota due to a dispute over duty-free EU meat exports to Turkey. Over quota imports of tomato paste to the EU are subject to a $15 \%$ tariff. In 2006, the tariff quota for prepared tomato decreased to 8,900 tons in order for a reduction in the most-favored nation duty to be applied at $100 \%$ (2006/999/EC: Decision No 2/2006 of the EC-Turkey Association Council of October 17, 2006, amending Protocols 1 and 2 to Decision No $1 / 98$ on the trade regime for agricultural products.) The nature of the dispute between Turkey and the EU over beef and live bovine animals is quite complicated to cover in here.
}

25 Interview with a Turkish official (May 29, 2009, Brussels). 
"compromise" mean different things to officials from different EU member states (Bellier 2000:67). Such differences in the culture of compromise can make it harder for the EU institutions themselves to attain a common European interest.

Like the French and Italians, the British Commission interlocutor concluded Turks use a courtier system rather than a college system. The prime minister is the sole decider on policy, without resorting much to technocratic expertise. In his court, no trade-offs exist between ministers and his personal advisers. Due to the high level of bureaucratic politics, his ministers may propose conflicting arguments and solutions depending on their institutional needs and demands. In the absence of a system of compromise, the prime minister decides what needs to be done and who should do it. Because the lower level bureaucracy has low authority in decision making-hence heavily depend on higher-level officials' making of policy decisions - they appear to act as simple conduits, implementing policies designed, defined, and decided elsewhere. ${ }^{26}$ However, unlike the French case, this Commission interlocutor argued there are no means to balance out the existing courtier networks surrounding the Turkish prime minister.

Because so few Turkish representatives actively participate in negotiations, despite their high numbers, Commission officials commonly assume that there is widespread inertia in the Turkish bureaucracy. Some Turkish bureaucrats agree. Accordingly, the passive presence of Turkish bureaucrats in meetings with the Commission could be explained by Turkish bureaucratic culture and how it responds to power inequities in its EU relations. On the surface, Turkish bureaucrats' sheer attendance and non-participation appear as simple "traditional" aspects of the Turkish bureaucratic culture-lack of institutional memory, absence of accumulation of knowledge, bureaucratic inertia, lack of systems of accountability, and power struggles between and within state organs as manifested at the individual bureaucratic level—all of which has been perfectly summed up by a Turkish bureaucrat: "In the Turkish state bureaucracy, one should act to be able to do something, not to be somebody. But in order to do something, you need to be somebody." 27 Lower level bureaucrats may not be as forthcoming with their opinions despite the fact that they hold necessary technical information, due to a fear of being sanctioned, one Commission official suggested. They worry that their comments would be deemed inappropriate by the heads of their unit or by other seniors in Ankara who may or may not be present at these meetings. ${ }^{28}$ Surely, officials from both sides run a critical account of each meeting, and those accounts get circulated and further circulated, as evidenced in my account above of the victorious comments of one Turkish public official after a meeting with the Commission in Brussels. Such representations may ultimately provoke rewards or

\footnotetext{
${ }^{26}$ In another case with an imperial cultural context, Uchiyamada (2004:7) makes a similar point regarding Japanese officials, who he described as "beautifully decorated surface matters." He associated lower level bureaucrats' acting like "subalterns, who are not allowed to express their views, [but] are nevertheless expected to be present to show their corporeal and collective conformity" to Japan's imperial history and its reflection in Japanese bureaucratic culture.

27 Interview with a Turkish official (May 29, 2009, Brussels). For an ethnographic study of Turkish bureaucracy from the peripheries of state power, see Alexander (2002).

28 Interview with a Commission official from DG MARKT (June 2, 2009, Brussels).
} 
sanctions. A Belgian Commission official suggested, however, that once Turkish bureaucrats at higher levels realize that their position is not under threat, they relax their authority over lower level officials. ${ }^{29}$ Others made similar remarks, but a few also pointed out that aspects of Turkish bureaucratic culture that result in inertia and other "bureaucratic abnormalities" could also be considered as indicators of the potential malleability of Turkey's bureaucracy from an EU perspective. Their Turkish colleagues who have to work their way through exiting bureaucratic channels agreed. One Turkish official confidently concluded: "When something needs to be done, it gets done!"30 But how could such malleable bureaucratic potentialities turn into bureaucratic realities? Any attempt in that regard, it seems, has to also deal with other aspects of the courtier system that are manifest in extrastatal spaces of politics and politicking, for example, by economic elites, on which fresh research is needed.

A more productive way to conceptualize bureaucratic stereotypes is to view them as "one of the currencies of social life," as Herzfeld (1992:72) suggests. Following James Scott, Chalfin (2010:51) argued: "The state ... is a formative space of sociality ... which requires mastery of distinct modes of self-presentation and communication." Stereotypes provide means for those involved to make sense of each other. As such, bureaucratic stereotypes such as inertia or the college-courtier axis "emerge from situated actors' relationships with the sources of power" (Herzfeld 1992:77). Hence, a more persuasive argument to counterbalance that of bureaucratic inertia is given by Heyman (2004:489) who argues that, "the results of bureaucratic action are not idiosyncrasies or failures but in some way reflections of the combination of various internal and external power relations surrounding the organization, often crystallized into patterns of organizational routine." He further suggested that anthropologists should "pay particular attention to the way bureaucrats go about their work, especially in the zone between official policy and unofficial routine and discretion, as clues to wider political arrangements and governing ideologies" (Heyman 2004:489). From this perspective, I conclude that Turkish bureaucratic "inertia" is actually a reaction to pressures from interests both at home and in Europe. When Turkish officials attempt to represent public interests in technical meetings with the Commission, whether the subject at hand is individual commodity exports or third-party free trade agreements, they commonly feel that they cannot say anything definitive to the meeting because those who they represent back in Turkey are reluctant to give them any definitive instructions except that "all is under study." 31 This kind of foot-dragging also happens on the EU side, as my earlier discussion on FTA negotiations illustrates, yet when the Commission does this, it is rarely characterized as "bureaucratic inertia."

\footnotetext{
${ }^{29}$ Interview with a Commission official from DG TRADE (February 4, 2009, Brussels).

30 Interview with a Turkish official (December 10, 2008, Brussels).

31 Interview with a senior-level bureaucrat from Turkey's Delegation to the EU (December 10, 2008, Brussels).
} 


\section{Conclusion: European integration from the margins}

This article has moved from the regional aims of the European Union within the capitalist world-system, to the political and economic processes of accession and economic integration, to the negotiations that have challenged this process of integration, and, finally, to the incompatible bureaucratic practices that reinforce conflicts of economic interests in the very processes of Turkey's EU integration. Here, there are two sides, one, a supra-governmental bureaucracy representing (and monopolizing access to) the full membership of the Union and, the other, a peripheral nominee for EU accession whose economic interests often come into conflict with the very people with whom they are negotiating. In such an imbalanced power situation, it might be no surprise that a proud and postimperial government such as the Turkish one would try to balance out its power deficit by the simple method of sending more delegates to meetings than the other side does. But this does not work the way the Turkish side expects. Congruent with the courtier system, sending such large delegations only serves to make the Turkish side appear to be more peripheral and "old-fashioned" in a setting where the EU markets itself as working largely on the collegial model. As a result, Turkey continues to lose on important economic matters such as tomato paste export quotas or, more significantly, the FTAs the EU signs with third countries. The negotiation process was supposed to move Turkey from limited economic integration to full political integration in the EU, but instead it lays bare the unequal power relations between core and periphery, since it reverses the momentum that was supposed to occur with the outset of the customs union itself.

Crystallized in customs union arrangements in operation for over a decade and a half now, deeper economic cooperation between the EU and Turkey did not fulfill Turkish expectations of enhanced political integration with the Union. Decoupled from a commitment to the country's EU membership prospect, arguments that are solely based on economic interests fail to convince both sides about the future viability of sustaining existing terms and conditions of Turkey's economic integration to the Union and its itinerant politics, especially in a context where those interests are seen to be increasingly competitive. In this study, I argued that problems in managing the Turkey-EU Customs Union as a macro-template for advanced economic integration are due to unequal power relations between the Union and Turkey. The disjuncture in the understanding of overall objectives of economic integration is also a strong factor. Each of these factors has everyday ramifications on individual actors; for these actors are increasingly disenfranchised from day-to-day negotiations. Techno-bureaucrats have historically been the main engineers and promoters of economic integration in the wider region. But they are also human beings whose actions and behaviors are both reflections of and constitutive of the wider political economic realities in which they live and operate. Despite the Commission's strong intentions to present the EU-Turkey Customs Union as a working relationship of economic integration, ethnographic analysis revealed that at the individual bureaucratic level this relationship is a failed association because promises of political membership are not fulfilled when the EU 
side stalls the process and the Turkish side fails to deliver reforms in a systematic way.

Failed promises of common interest formation in economy and politics in the case of the Turkey-EU Customs Union left officials from both sides feeling that they had no option but to disengage from mutually sustainable interests. My above exposé of this disintegration process indicates that mutually sustainable futures in the European region between capitalism's old centers and newly emerging periphery centers depend on politicians' and bureaucrats' working out of their differences via democratic channels and not on enhanced bureaucratic politicking. This study aims to be a first step in that long and narrow road, whereby political economy and its cultural forms are better understood and mutually agreed. In considering the fate of states and peoples, a customs union, for example, is never simply a merger of different customs regimes. Tariffs and other customs levies, once tools of protection for nationally defined economies, have never been simple technical mechanisms or policies but are "among the many constituents of the structure of global economy, along with hierarchy of core and periphery" (Roseberry 2002:68). To understand Turkey's aspirations to become part of the European core, and the global structural power relations and local bureaucratic conditions that inhibit it, we must attend to both the political economies and the cultural settings in which the former turned to be an everyday phenomenon. In an increasingly globalized world, others such as the ASEAN and the Mercusor take the EU as a model for successful regional integration. Future studies of the interrelations between political economic inequalities, interests, and how they play out in everyday bureaucratic practices will illuminate these interrelated processes in either the context of regional integration or otherwise.

Acknowledgments An internship with the European Economic and Social Committee during initial stages of fieldwork in Brussels from February to May 2009 provided me with the time, energy, encouragement, and insider's access to Eurocracy. Fieldwork in Brussels from June 2008 to June 2009 was generously funded by the Wenner Gren Foundation for Anthropological Research Inc. (Grant Nr: 7783). I thank Thomas M. Wilson, Denis O'Hearn and two anonymous reviewers for their valuable comments.

\section{References}

Abélès, Marc., and Irène. Bellier. 1996. La Commission Européenne: du compris culturel à la culture politique du compris. Revue Française de Science Politique 46(3): 431-455.

Abélès, Marc., Irène. Bellier, and Maryon. McDonald. 1993. Approche anthropologique de la Commission Européenne. Brussels: European Commission.

Abélès, Marc. 1992. La vie quotidienne au parlement européen. Paris: Hachette.

Abélès, Marc. 2000. Virtual Europe. In An anthropology of European Union: Building, imagining and experiencing the new Europe, ed. Irène. Bellier, and Thomas.M. Wilson, 31-52. Oxford: Berg Publishers.

Abélès, Marc. 2002. Political anthropology of European institutions: Tensions and stereotypes. In Fremdbilder-Feindbilder-Zerrbilder: zur Wahrnehmung und diskursiven Konstruktion des Fremden, ed. K. Liebhart, E. Menasse, and H. Steinert, 240-253. Klagenfurt: Drava.

Ahearn, Raymond J. 2011. Europe's preferential trade agreements: Status, content, and implications. CRS Report for Congress R41143.

Alexander, Catherine. 2002. Personal states: Making connections between people and bureaucracy in Turkey. New York: Oxford University Press. 
Arrighi, Giovanni. 1994. The long twentieth century: Money, power, and the origins of our times. London: Verso.

Bellier, Irène. 2000. The European Union, identity politics and the logic of interest representation. In An anthropology of European Union: Building, imagining and experiencing the new Europe, ed. Irène. Bellier, and Thomas.M. Wilson, 53-73. Oxford: Berg.

Bellier, Irène. 2002a. European identity, institutions and languages in the context of enlargement. Journal of Language and Politics 1(1): 85-114.

Bellier, Irène. 2002b. In and out, fieldwork in a political space: The case of the European Commission. Österreichische Zeitschrift für Politikwissenschaft 31(2): 205-216.

Bellier, Irène. 2004. The European Commission between acquis communautaire and enlargement. In The changing European Commission, ed. Dionyssis.G. Dimitrakopoulos, 138-150. New York: Manchester University Press.

Beyers, Jan., and Jarle. Trondal. 2004. How nation states 'hit' Europe: Ambiguity and representation in the European Union. West European Politics 27(5): 919-942.

Blom Hansen, Thomas., and Finn. Stepputat. 2001. Introduction. In States of imagination: Ethnographic explorations of the postcolonial state, ed. Blom Thomas. Hansen, and Finn. Stepputat, 1-40. Durham: Duke University Press.

Bourdieu, Pierre. 1996 [1989]. The state nobility: Elite schools in the field of power. Cambridge: Polity Press.

Bourdieu, Pierre. 1999. Rethinking the state: Genesis and structure of the bureaucratic field. In State/ Culture. State-formation after the cultural turn, ed. George. Steinmetz, 53-75. Ithaca: Cornell University Press.

Bunker, Stephen.G., and Paul. Ciccantell. 2005. Globalization and the race for resources. Baltimore: Johns-Hopkins University Press.

Burawoy, Michael., et al. 2000. Global ethnography: forces, connections, and imaginations in a postmodern world. Berkeley: University of California Press.

Chalfin, Brenda. 2010. Neoliberal frontiers: An ethnography of sovereignty in west Africa. Chicago: University of Chicago Press.

Cohen, Abner. 1980. Dramas and politics in the development of a London carnival. Man 15(1): 65-87.

Déloye, Yves. 2000. Exploring the concept of European Citizenship: A socio-historical approach. Yearbook of European Studies 14: 197-219.

Eder, Mine. 2001. Deeper concessions and rising barriers to entry: New regionalism for Turkey and Mexico. Studies in Comparative International Development 36(3): 29-57.

Geuijen, Karin., Paul. 't Hart, and Kutsal. Yesilkagit. 2007. Dutch Eurocrats at work: Getting things done in Europe. In Observing government elites: Up close and personal, ed. R.A.W. Rhodes, Paul. 't Hart, and Mirko. Noordegraaf, 131-159. London: Palgrave Macmillan.

Geuijen, Karin., Paul. 't Hart, Sebastiaan. Princen, and Kutsal. Yesilkagit. 2008. The new Eurocrats: National civil servants in EU policymaking. Amsterdam: Amsterdam University Press.

Graham, Mark. 2002. Emotional bureaucracies: Emotions, civil servants, and immigrants in the Swedish welfare state. Ethos 30(3): 199-226.

Haas, Ernst.B. 1964. Technocracy, pluralism and the new Europe. In A new Europe?, ed. S.R. Graubard, 62-88. Boston: Houghton Mifflin.

Handelman, Don. 1978. Introduction: A recognition of bureaucracy. In Bureaucracy and worldview: Studies in the logic of official interpretation, ed. Don. Handelman, and Elliot. Leyton, 1-14. Newfoundland: Institute of Social and Economic Research, Memorial University of Newfoundland.

Harmsen, Robert., and Thomas.M. Wilson. 2000. Introduction: Approaches to Europeanization. Yearbook of European Studies 14: 13-26.

Harmsen, Robert. 1999. The Europeanization of national administrations: A comparative study of France and the Netherlands. Governance: An International Journal of Policy and Administration 12(1): 81-113.

Herzfeld, Michael. 1992. The social production of indifference: Exploring the symbolic roots of western bureaucracy. Chicago: University of Chicago Press.

Henderson, W.O. 1981. The German Zollverein and the European Economic Community. Journal of Institutional and Theoretical Economics 187(3): 491-507.

Hertz, Ellen. 1998. The trading crowd: An ethnography of the Shanghai Stock Market. Cambridge: Cambridge University Press.

Heyman, Josiah.Mc.C. 2004. The anthropology of power-wielding bureaucracies. Human Organization 63(4): 487-500. 
Hopkins, Terence.K. 1957. Sociology and the substantive view of economy. In Trade and market in the early empires: Economies in history and theory, ed. Karl. Polanyi, Conrad.M. Arensberg, and Harry.W. Pearson, 271-306. Glencoe: Free Press.

Kassim, Hussein., B. Guy Peters, and Vincent. Wright (eds.). 2000. The national co-ordination of EU policy: The domestic level. Oxford: Oxford University Press.

Kassim, Hussein., B. Guy Peters, and Vincent. Wright (eds.). 2001. The national co-ordination of EU policy: The European level. Oxford: Oxford University Press.

Kearney, Michael. 1995. The local and the global: The anthropology of globalization and transnationalism. Annual Review of Anthropology 24: 547-565.

Keohane, R.O. 2002. Ironies of sovereignty: The European Union and the United States. Journal of Common Market Studies 40(4): 743-765.

Kertzer, David. 1988. Ritual, politics and power. New Haven: Yale University Press.

Keskin, Yildirim. 2002. Avrupa Yollarında Türkiye: Edebiyatla Karısıl Diplomasi Anıları (1965-2000) [Turkey on the roads to Europe: Literary Diplomatic Memoirs (1965-2000)]. Istanbul: Bilgi.

Kirisci, Kemal., and Neslihan. Kaptanoglu. 2011. The politics of trade and Turkish foreign policy. Middle Eastern Studies 47(5): 705-724.

Kramer, Heinz. 1996. The EU-Turkey customs union: Economic integration amidst political turmoil. Mediterranean Politics 1(1): 60-75.

Laffan, Brigid. 1996. The politics of identity and political order in Europe. Journal of Common Market Studies 34(1): 81-102.

Laffan, Brigid. 2004. The European Union and its institutions as "identity builders". In Transnational encounters: Becoming European in the EU, ed. Richard.K. Herrmann, Thomas. Risse-Kappen, and Marilynn.B. Brewer, 75-96. Oxford: Rowman and Littlefield Publishers.

Lewis, Jeffrey. 2009. National interests. In The SAGE handbook of European studies, ed. Chris. Rumford, 110-130. London: SAGE.

Malaby, Thomas.M. 2002. Making change in the new Europe: Euro competence in Greece. Anthropological Quarterly 75(3): 591-597.

March, James.G., and Johan.P. Olsen. 1998. The institutional dynamics of international political orders. International Organization 52(4): 943-969.

McDonald, Maryon. 1996. 'Unity in diversity': Some tensions in the construction of Europe. Social Anthropology 4(1): 47-60.

McDonald, Maryon. 2000. Accountability, anthropology and the European Commission. In Audit cultures: Anthropological studies in accountability, ethics and the academy, ed. Marilyn. Strathern, 106-132. London: Routledge.

Meehan, Elizabeth. 2000. Europeanization and Citizenship of the European Union. Yearbook of European Studies 14: 157-177.

Misrahi, Frédéric. 2009. Nuancing conventional wisdom on state-business relations in Turkey: the case of technical product regulations. European Journal of Turkish Studies [Online] 9 http://ejts.revues.org/index3804.html.

Misrahi, Frédéric. 2010. What prospects for the lifting of technical trade barriers in the Mediterranean? Insights from the Turkish case. Mediterranean Politics 15(2): 189-209.

Muntigl, Peter., Gilbert. Weiss, and Ruth. Wodak. 2000. European Union discourses on un/employment: An interdisciplinary approach to employment policymaking and organizational change. Amsterdam and Philadelphia: John Benjamins Publishing Company.

Navaro-Yashin, Yael. 2006. Affect in the civil service: A study of a modern state-system. Postcolonial Studies 9(3): 281-294.

Neveu, Catherine. 2000. European Citizenship, Citizens of Europe and European Citizens. In An anthropology of European Union: Building, imagining and experiencing the new Europe, ed. Irène. Bellier, and Thomas.M. Wilson, 119-135. Oxford: Berg Publishers.

O'Hearn, Denis. 2001. The Atlantic economy: Britain, the US and Ireland. Manchester: Manchester University Press.

Ong, Aihwa. 2000. Graduated sovereignty in south-east Asia. Theory, Culture and Society 17(4): 55-75.

Page, Edward.C. 1997. People who run Europe. Oxford: Clarendon Press.

Peers, Steve. 1996. Living in sin: Legal integration under the EC-Turkey Customs union. European Journal of International Law 7(3): 411-430.

Polanyi, Karl. 1957. The great transformation. New York: Rinehart.

Reinhardt, Nickolas. 2004. Pecuniary identity and European integration. In Who are the Europeans now?, ed. Edward. Moxon-Browne, 112-135. Aldershot: Ashgate. 
Rosamond, Ben. 2002. Imagining the European economy: 'Competitiveness' and the social construction of 'Europe' as an economic space. New Political Economy 7(2): 157-177.

Roseberry, William. 2002. Understanding capitalism-Historically, structurally, spatially. In Locating capitalism in time and space: Global restructurings, politics, and identity, ed. David. Nugent, 61-79. Stanford: Stanford University Press.

Sassen, Saskia. 1996. Losing control? Sovereignty in an age of globalization. New York: Columbia University Press.

Sassen, Sakia. 2006. Territory, authority, and rights: From medieval to global assemblages. Princeton: Princeton University Press.

Schmid, Dorothée. 2004. The use of conditionality in support of political, economic and social rights: Unveiling the Euro-Mediterranean partnership's true hierarchy of objectives? Mediterranean Politics 9(3): 396-421.

Shore, Cris., and Annabel. Black. 1994. Citizen's Europe and the construction of European identity. In The anthropology of Europe: Identities and boundaries in conflict, ed. V.A. Goddard, J.R. Llobera, and C. Shore, 275-298. Oxford: Berg Publishers.

Shore, Cris., and Daniela. Baratieri. 2006. Crossing boundaries through education: European schools and the suppression of nationalism. In Crossing European boundaries: Beyond conventional geographical categories, ed. J. Stacul, C. Moutsou, and H. Kopina, 23-40. New York: Berghahn.

Shore, Chris. 2000. Building Europe. The cultural politics of European integration. London: Routledge.

Shore, Cris. 2002. Introduction: Towards an anthropology of elites. In Elite cultures: Anthropological perspectives, ed. C. Shore, and S. Nugent, 1-21. London: Routledge.

Shore, Cris. 2006. 'Government without statehood'? Anthropological perspectives on governance and sovereignty in the European Union. European Law Journal 12(6): 709-724.

Shore, Cris. 2007. European integration in anthropological perspective: Studying the 'culture' of the EU civil service. In Observing government elites: Up close and personal, ed. R.A.W. Rhodes, Paul. 't Hart, and Mirko. Noordegraaf, 180-205. London: Palgrave Macmillan.

Sideri, Katerina. 2005. The European Commission and the law-making process: Compromise as a category of praxis. International Journal of Law in Context 1(2): 155-182.

Stirrat, R.L. 2000. Cultures of consultancy. Critique of Anthropology 20(1): 31-46.

Stoler, Ann.Laura. 2004. Affective states. In A companion to the anthropology of politics, ed. David. Nugent, and Joan. Vincent, 4-20. Oxford: Blackwell.

Teivainen, Teivo. 2009. The pedagogy of global development: The promotion of electoral democracy and the Latin Americanisation of Europe. Third World Quarterly 30(1): 163-179.

Thedvall, Renita. 2006. Eurocrats at work: negotiating transparency in postnational employment policy. Stockholm Studies in Social Anthropoloy, 58. Stockholm: Department of Social Anthropology, Stockholm University.

Thedvall, Renita. 2007. The EU's nomads: National Eurocrats in European policymaking. In Observing government elites: Up close and personal, ed. R.A.W. Rhodes, Paul. 't Hart, and Mirko. Noordegraaf, 160-179. London: Palgrave Macmillan.

Tilly, Charles. 1985. War making and state making as organized crime. In Bringing the state back in, ed. P.B. Evans, D. Rueschemeyer, and T. Skocpol. Cambridge: Cambridge University Press.

Tomich, Dale. 2003. Through the prism of slavery: Labor, capital, and world economy. Lanham, MD: Rowman \& Littlefield.

Tsing, Anna. 2000. The global situation. Cultural Anthropology 15(3): 327-360.

TUSIAD. 2008a. Current situation in the Turkey-EU Customs Union relations. Info note: TS/BXL/08-05.

TUSIAD. 2008b. EU's free trade agreements with third countries and their impact on Turkey by way of customs union. Info note: TS/DIS/2008-08.

TUSIAD. 2010. Current situation in the Turkey-EU Customs Union relations. Info note: TS/BXL/10-03.

Uchiyamada, Yasushi. 2004. Architecture of immanent power: Truth and nothingness in a Japanese bureaucratic machine. Social Anthropology 12(1): 3-23.

Unalan, Dilek., and Richard. Cowell. 2009. Adoption of the EU SEA directive in Turkey. Environmental Impact Assessment Review 29: 243-251.

Ülgen, Sinan., and Yiannis, Zahariadis. 2004. The future of Turkish-EU trade relations: Deepening vs. widening. EU-Turkey Working papers 5. Brussels: Centre for European Policy Studies.

Ülgen, Sinan. 2006. Turkish business and EU accession. Centre for European Reform Essays, December. London: Centre for European Reform.

Wallerstein, Immanuel. 2004. World-systems analysis: An introduction. Durham, NC: Duke University Press. 
Wodak, Ruth. 2009. The discourse of politics in action: Politics as usual. New York: Palgrave Macmillan.

Wolters, Willem.G. 2001. The Euro: Old and new boundaries in the use of money. Anthropology Today 17(6): 8-12.

Wolf, Eric.R. 1992. Europe and the people without history. Berkeley: University of California Press.

Yilmaz, Gaye. 2007. Turkey: WTO negotiations in the shadow of the European Union. In Strategic arena switching in international trade negotiations, ed. Wolfgang. Blaas, and Joachim. Becker, 241-269. London: Ashgate. 